Poznań

\title{
Potencjał protestów motywowanych ekonomicznie - przypadek współczesnej Federacji Rosyjskiej
}

\begin{abstract}
Streszczenie: Działalność rosyjskiej opozycji politycznej została znacznie ograniczona po masowych protestach z przełomu 2011 i 2012 r. Liczne zmiany w prawie spowodowały istotne zmniejszenie się liczby podmiotów, które opozycyjną działalność w sferze polityki mogłyby kontynuować. Jednocześnie, pogłębiający się kryzys gospodarczy i pogarszająca się sytuacja ekonomiczna szerokich mas Rosjan, ujawniła niezagospodarowaną dotąd przestrzeń, w której w ostatnich miesiącach zaczęło się ujawniać niezadowolenie rosyjskich obywateli z poczynań władzy. Celem artykułu jest analiza aktualnej sytuacji społeczno-gospodarczej Federacji Rosyjskiej oraz wskazanie na ewentualne przejawy ekonomicznie motywowanych protestów Rosjan. Podstawą analizy będą wskaźniki makroekonomiczne, wyniki badań rosyjskiej opinii publicznej oraz analiza informacji o ewentualnych wydarzeniach o charakterze protestu zamieszczonych w rosyjskich mediach (głównie społecznościowych). W efekcie artykuł może stać się przyczynkiem do dyskusji na temat potencjalnych relacji pomiędzy brakiem stabilności w kwestiach poczucia bezpieczeństwa ekonomicznego i socjalnego a skłonnością do udziału w protestach przeciwko władzy.
\end{abstract}

Słowa kluczowe: opozycja w Federacji Rosyjskiej; protesty przeciwko władzy; gospodarka Rosji; społeczne postrzeganie kryzysu

D ziałalność rosyjskiej opozycji politycznej została znacznie ograniczona po masowych protestach z przełomu 2011 i 2012 r. Liczne zmiany w prawie spowodowały istotne zmniejszenie się liczby podmiotów, które opozycyjną działalność w sferze polityki mogłyby kontynuować. Jednocześnie, pogłębiający się kryzys gospodarczy i pogarszająca się sytuacja ekonomiczna szerokich mas Rosjan, ujawniła niezagospodarowaną dotąd przestrzeń, w której w ostatnich miesiącach nieznacznie zaczęło się ujawniać niezadowolenie rosyjskich obywateli z poczynań władzy.

Celem artykułu jest analiza aktualnej sytuacji społeczno-gospodarczej Federacji Rosyjskiej oraz wskazanie na ewentualne przejawy ekonomicznie motywowanych protestów Rosjan. Dodatkowo, istotnym elementem będzie również analiza społecznej gotowości do ewentualnego udziału w protestach, a także próba określenia poziomu poparcia społeczeństwa dla ewentualnych inicjatyw podejmowanych w sferze publicznych protestów. Co ważne, artykuł obejmie też społeczny odbiór kryzysu gospodarczego, co może być użyteczne podczas prób prognozowania potencjalnych wystąpień. Wartość stanowi również sformułowany przez autorkę katalog czynników, które ewentualne protesty rosyjskich obywateli mogłyby blokować. W efekcie poddana weryfikacji zostanie następująca hipoteza: trudna sytuacja gospodarcza dotkliwie wpływająca na jakość życia społeczeństwa może być katalizatorem masowych protestów przeciwko władzy.

Podstawę analizy stanowią wskaźniki makroekonomiczne, wyniki badań rosyjskiej opinii publicznej oraz analiza informacji o ewentualnych wydarzeniach o charakterze 
protestu zamieszczonych w rosyjskich mediach (głównie społecznościowych). W efekcie wystapienie może stać się przyczynkiem do dyskusji na temat potencjalnych inklinacji pomiędzy brakiem stabilności w kwestiach poczucia bezpieczeństwa ekonomicznego i socjalnego a skłonnością do udziału w protestach przeciwko władzy.

\section{Aktualna sytuacja gospodarcza Federacji Rosyjskiej}

Okres sprawowania władzy przez Władimira Putina często jest określany czasem stabilnego rozwoju gospodarczego, tak bardzo kontrastujący wobec załamania gospodarczego z drugiej połowy lat 90 . Jednak warto pamiętać, iż pierwsze problemy w sferze ekonomicznej pojawiły się w momencie, kiedy cały świat borykał się z kryzysem finansowym. W 2009 r. PKB Federacji zanotowało spadek aż o 11,20\% (wykres 1), poziom inflacji wynosił ponad 15\% (Rosja - Inflacja), a cena ropy naftowej spadła do niespełna 45 dolarów za baryłkę (wykres 2). Jednak w tamtym kryzysowym momencie Rosja dysponowała gigantycznymi rezerwami zgromadzonymi głównie dzięki wysokim cenom surowców, szczególnie ropy naftowej, której cena osiagała rekordy jeszcze w 2008 r. (ponad 145 dolarów za baryłkę). Dodatkowo, pomimo niekorzystnych wskaźników makro- i mikroekonomicznych, realne dochody Rosjan podczas kryzysu w 2009 r. wciąż rosły, co wynikało właśnie z przekierowania na rynek znacznej ilości pieniędzy z rezerw walutowych (Łobuszewska, Kazimierska, Mańkowski, 2015, s. 20). Dlatego też, trudno wykazywać podobieństwa pomiędzy kryzysem sprzed blisko siedmiu lat a aktualnymi trudnościami, z którymi mierzy się rosyjska gospodarka.

Wykres 1. Roczne tempo wzrostu PKB w Federacji Rosyjskiej w latach 1996-2016

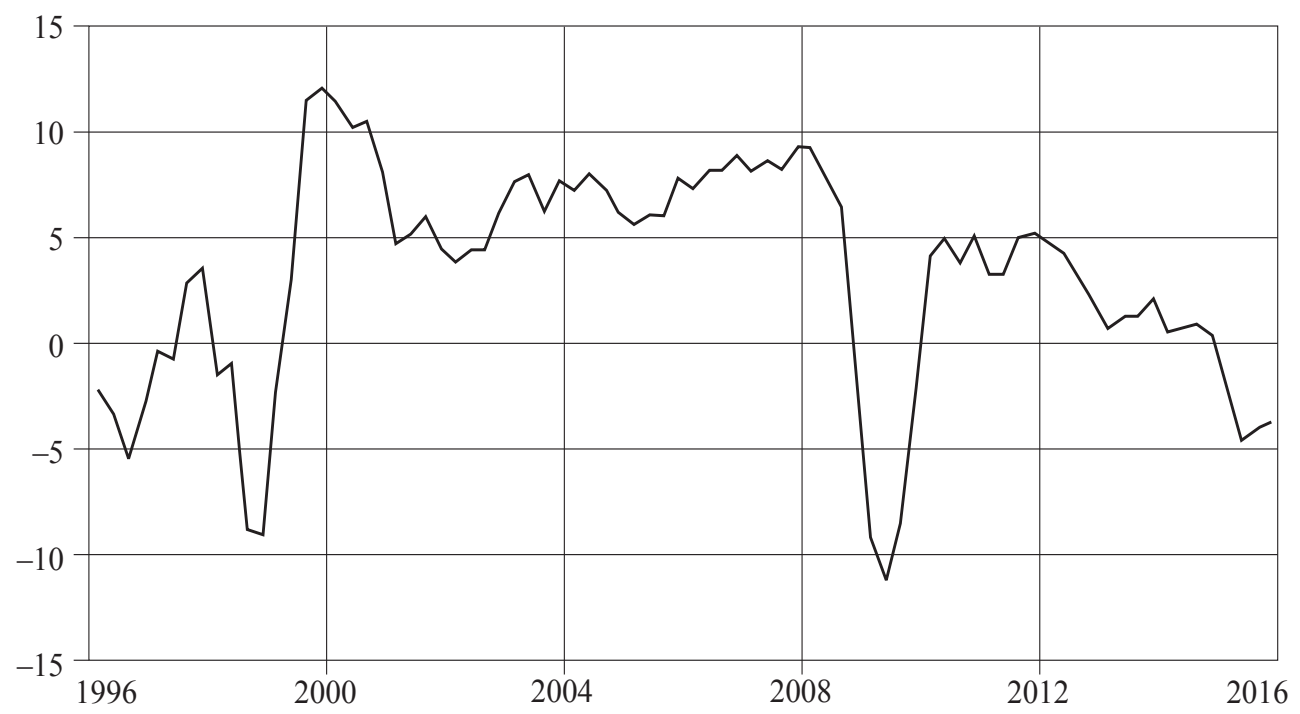

Źródło: Rosja - Roczne tempo wzrostu. 
Wykres 2. Poziom ceny ropy naftowej w dolarach za baryłkę w latach 1996-2016

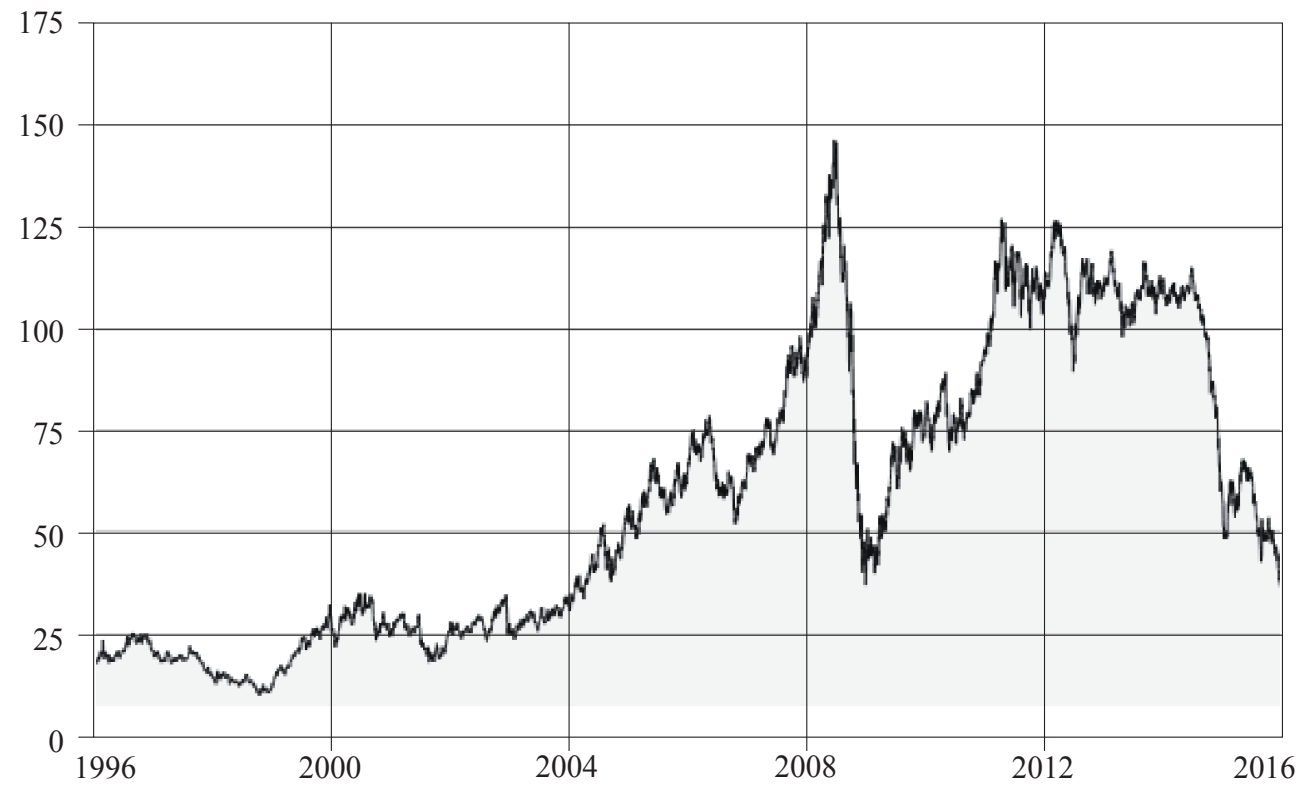

Źródło: Ropa - notowania surowców.

Kiedy w połowie grudnia $2014 \mathrm{r}$. doszło do kryzysu na rosyjskim rynku finansowym, władze Federacji nie dysponowały już tak gigantycznymi rezerwami, które pomogłyby szybko odpowiedzieć na spadki, a dodatkowo rosyjska gospodarka została w znaczny sposób odcięta od możliwości dofinansowania jej zagranicznymi kredytami i inwestycjami (efekt zachodnich sankcji po zaangażowaniu Rosji w konflikt na wschodzie Ukrainy). Wprawdzie Bank Centralny interweniował na rynku walutowym - co pozwoliło powstrzymać radykalnie spadający kurs rubla (stracił na wartości wobec dolara blisko $40 \%$ ), jednak słaba waluta, niska cena ropy naftowej oraz rosnąca inflacja okazały się być tylko objawami postępującego już od jakiegoś czasu kryzysu rosyjskiej gospodarki (Menkiszak, Fischer, 2014). Według analityków Ośrodka Studiów Wschodnich, można wyróżnić trzy główne źródła aktualnych problemów: po pierwsze, struktura rosyjskiej gospodarki oparta na eksporcie surowców energetycznych (zapewnia 50\% dochodów budżetu i stanowi 20\% PKB Federacji) i inwestycjach skupionych w tym sektorze; po drugie, polityka zagraniczna, w której dominują agresywne zachowania w stosunku do Ukrainy (aneksja Krymu, zaangażowanie w konflikt na wschodzie) oraz pogarszające się z tego powodu relacje z Zachodem (zachodnie sankcje i rosyjskie kontrsankcje w znaczący sposób wpływające na rosyjską gospodarkę, odpływ zagranicznych inwestycji); po trzecie, gwałtowny spadek cen ropy naftowej, zapoczątkowany już w połowie 2014 r. i wciąż niepowstrzymany, co stanowi poważne wyzwanie dla budżetu opartego w znacznej części właśnie o dochody ze sprzedaży ropy i gazu (Menkiszak, Fischer, 2014). Wyczerpywanie się modelu zapoczątkowanego w roku 2000 jest wyraźne, brakuje natomiast pomysłu, czym zastapić opartą o surowce gospodarkę, której wszystkie najważniejsze wskaźniki wciąż spadają, nie zapowiadając poprawy w najbliższym czasie. 
Kryzys rosyjskiej gospodarki to również ogromne wyzwanie dla rządu Federacji, który jest odpowiedzialny za jej budżet. Korekty, i to znacznej, wymagał już plan dochodów i wydatków państwa na rok 2015, kiedy okazało się, że cena ropy naftowej z zakładanych 100 dolarów spadła do około 50. Zmiany wprowadzone do budżetu w marcu 2015 r. uwzględniały nie tylko niższe dochody ze sprzedaży surowców, ale również systematycznie wzrastający poziom inflacji (ponad 12\%) oraz niestabilny i wciąż tracący w stosunku do dolara kurs rubla. Dodatkowo, należało wziąć pod uwagę również prognozy inwestycyjne - spadek o $14 \%$, zmniejszenie importu o 40\%, a także płacy realnej o 6\% (Fischer, 2015). Tak znaczne ograniczenia wpływów do budżetu musiały znaleźć odzwierciedlenie po stronie wydatków, głównie w sferze oświaty, ochrony zdrowia i kultury. Co istotne, zamiast działań zmierzających do modernizacji rosyjskiej gospodarki, rząd Federacji skupił się przede wszystkim na utrzymywaniu status quo z wciąż wzrastającymi wydatkami na obronność oraz dotacjami dla sektora socjalnego, który ma zapewnić bezpieczeństwo wewnętrzne (Fischer, 2015). Takie doraźne działania mające na celu jedynie przynajmniej próby równoważenia budżetu, nie rozwiązują najważniejszego problemu - wymagającej strukturalnych zmian i pogłębiającej się w kryzysie rosyjskiej gospodarki.

W oparciu o założenia uwzględniające kryzys powstawał również plan budżetu na rok 2016. Eksperci zauważają jednak, iż przyjęte założenia - cena ropy naftowej na poziomie 50 dolarów za baryłkę, inflacja na poziomie $6,4 \%$, wzrost PKB o $0,7 \%$ oraz kurs rubla do dolara na poziomie 63,3 - są zbyt optymistyczne i będą wymagały wielokrotnej korekty (Domańska, 2015; Kośka, 2015). Już od początku 2016 r. można obserwować wciąż spadającą cenę ropy naftowej, która na początku lutego wynosiła niewiele ponad 34 dolary za baryłkę, nierealny wydaje się również spadek inflacji, której poziom na koniec 2015 r. wciąż wynosił blisko 13\% (Rosja - Inflacja). Jednak, nawet w przypadku tak optymistycznych prognoz, które sformułował rząd Federacji, w rosyjskim budżecie niezbędne były znaczne cięcia wydatków - nie uzyskano wprawdzie zgody na redukcję wydatków na armię i obronność, a nakłady na politykę społeczną nawet nieznacznie wzrosną, cięcia będą jednak dotyczyły w znacznym stopniu edukacji i ochrony zdrowia (Domańska, 2015). Warto zwrócić uwagę na zagrożenie, iż „konstruując budżet z wyraźnym pominięciem dotowania nauki i badań, Rosja dobrowolnie rezygnuje z podążania za odbywającymi się na świecie zmianami i w efekcie pozostaje w tyle za państwami Zachodu" (Kośka, 2015).

Co istotne jednak, tak optymistyczne założenia budżetowe oraz brak cięć w sferze wydatków socjalnych, wskazywać może polityczno-propagandową funkcję aktualnego budżetu - we wrześniu 2016 r. mają się odbyć wybory do Dumy Państwowej, a na 2018 r. zaplanowane są wybory prezydenckie. Według Marii Domańskiej z Ośrodka Studiów Wschodnich ,świadczą o tym zarówno plany dodatkowej indeksacji emerytur tuż przed wyborami parlamentarnymi, jak i dążenie do odłożenia trudnych decyzji (podniesienie wieku emerytalnego, wzrost podatków) na okres po 2018 roku. Władze najpewniej będą dążyć do zachowania na wyborczy rok 2018 „,żelaznej” rezerwy w postaci środków Funduszu Dobrobytu Narodowego, co może je skłonić do zwiększania długu państwowego w miarę wyczerpywania się Funduszu Rezerwowego" (Domańska, 2015). Zorientowany na politykę obronną oraz społeczną budżet zadba o twardy elektorat W. Putina, który docenia działania mające na celu 
uwydatnienie rosyjskiej polityki imperialnej, a także jest uzależniony od transferów ze strony państwa.

\section{Prognozy dla gospodarki rosyjskiej}

Optymistyczne prognozy dla rosyjskiej gospodarki formułują głównie rosyjscy politycy. W grudniu 2015 r. rosyjski prezydent W. Putin przekonywał, iż pomimo spadku PKB, wysokiej inflacji oraz zmniejszających się inwestycji i dochodów ludności, „szczyt kryzysu gospodarka ma już za sobą [...] Te liczby trzeba znać i odpychać się od nich" (Putin). Premier Federacji Dmitrij Miedwiediew podkreślał natomiast, że w sytuacji, kiedy najważniejsze rynki finansowe zamknęły się na Rosję, ona „,dowiodła samowystarczalności swojej gospodarki" (Miedwiediew).

Według rosyjskich mediów te optymistyczne prognozy potwierdzają międzynarodowe agencje ratingowe, które zapowiadają wzrost rosyjskiej gospodarki. Ekonomistka Agencji Standard\&Poor's ds. Rosji Tatiana Łysienko informuje, iż jej agencja prognozuje „stabilizację kursu waluty i zmniejszenie tempa inflacji do 6-7\% pod koniec 2016 roku”, natomiast Starszy dyrektor w grupie analitycznej Fitch ds. suwerennych ratingów Charles Seville „spodziewa się stabilizacji gospodarki w 2016 roku przy wzroście w ciaggu roku o około 0,5\% i jego przyspieszeniu do 1,5\% w 2017 roku" (Co czeka). Dodatkowo, T. Łysienko podkreśla, iż „W chwili obecnej agencje oceniają rozwój sytuacji w gospodarce raczej jako stabilny, co odzwierciedliła w najnowszym ratingu agencja Moody's, gdy polepszyła do stabilnego prognozę suwerennego ratingu Rosji” (Co czeka).

Jednak w przestrzeni medialnej pojawiają się również mniej optymistyczne dla przyszłości rosyjskiej gospodarki prognozy. Ekonomiści Agencji Bloomberg zaliczyli Rosję do grupy pięciu najgorszych gospodarek w $2016 \mathrm{r}$. Twierdzą oni, iż istnieje duże prawdopodobieństwo wystąpienia recesji, a pomimo dużych spadków PKB w 2015 r., szczyt spadków jeszcze przed Rosją - może to być jeden z najbardziej przedłużających się kryzysów w Rosji od ponad 20 lat (Bloomberg).

Sceptyczny wobec prognoz rychłego zakończenia kryzysu w Rosji jest również Władisław Inoziemcew (wybitny rosyjski ekonomista, Dyrektor Centrum Badań Społeczeństwa Postindustrialnego), który twierdzi, iż pomimo powolnej stabilizacji sytuacji w gospodarce, kluczowe dla jej dalszych losów będą wydarzenia roku 2016. Zwraca on uwagę, iż pomimo odnotowywanych przez sektor korporacyjny zysków, kluczowe dla jego rozwoju gałęzie - takie jak budownictwo, gastronomia, transport lotniczy, handel nieruchomościami, turystyka - notują straty, a spora część przedsiębiorstw znajduje się na granicy bankructwa. Jeśli w ciągu najbliższych kilku miesięcy nie pojawią się sygnały o przezwyciężeniu kryzysu, konsumenci ograniczą wydatki, a balansujące na granicy nierentowności przedsiębiorstwa zostaną zamknięte, co tylko pogłębi recesję. Dodatkowo, można dziś w Rosji obserwować krach na rynku nieruchomości (oraz innych trwałych dóbr), co powoduje zastój w budownictwie, a także kryzys w systemie bankowym, przejawiający się odbieraniem licencji kolejnym bankom (Inoziemcow, 2015). Dlatego, choć pojawiają się licznie optymistyczne prognozy, decydujące będą dopiero pierwsze miesiące 2016 r., ponieważ wciąż brakuje jednoznacznego impulsu sprzyjającemu poprawie sytuacji rosyjskiej gospodarki. 


\section{Spoleczny odbiór kryzysu gospodarczego}

Rok 2015 był według analityków Centrum Lewady pierwszym od początku XXI wieku, w którym realne dochody ludności zmniejszały się niemal bez przerwy. Blisko połowa dorosłych obywateli Federacji stwierdziła w grudniu 2015 r., że sytuacja finansowa ich rodziny uległa pogorszeniu, a tylko 5\% przyznało, że finansowo żyje im się lepiej. W stosunku do roku 2014, spadła również liczba osób, które oczekują szybkiego zakończenia kryzysu (co trzeci Rosjanin pod koniec 2014 r. oraz co czwarty pod koniec 2015 r. oczekiwał szybkiej poprawy). Dodatkowo, wzrosła - do blisko $60 \%$ - liczba osób niemogących nic zaoszczędzić, przeznaczając całe dochody na żywność i - rzadziej - odzież (Tрудный). Rosjanie odczuwają kryzys w zmniejszających się realnych dochodach, a dodatkowo, spora cześć z nich nie spodziewa się szybkiej poprawy sytuacji.

Według Centrum Analitycznego Lewady pensje i emerytury są jedynym źródłem dochodów dla prawie wszystkich rosyjskich obywateli. Oszczędnościami - zwykle niewielkimi, pozwalającymi przetrwać maksymalnie kilka miesięcy - dysponuje tylko co trzeci Rosjanin. Jest to istotne ze względu na specyfikę rosyjskiego rynku pracy - w sytuacjach kryzysu większość firm nie zwalnia swoich pracowników, a jedynie redukuje płace lub zawiesza ich wypłacanie. Takie kryzysowe działania pracodawców odczuła w 2015 r. połowa Rosjan. Zmniejszone dochody powodują tzw. zjawisko godnego ubóstwa, którym można określić sytuację, kiedy pieniądze z pensji lub emerytury wystarczają tylko na naprawdę niezbędne wydatki, głównie podstawową żywność, zdecydowanie rzadziej tanią odzież ${ }^{1}$. W efekcie znaczna część Rosjan, choć odczuwa kryzys, dzięki intensywnym poszukiwaniom tańszych zamienników wielu produktów żywnościowych, może zaspokoić swoje podstawowe potrzeby.

\section{Prognozy na nowy rok 2016 (społeczne oczekiwania)}

W odpowiedzi na pytania o prognozy na nowy od początku kryzysu, czyli od końca 2014 r., coraz więcej Rosjan coraz mniej optymistycznie patrzy w przyszłość. U progu 2015 oraz 2016 r. blisko co dziesiąty Rosjanin był przekonany, iż w nowym roku będzie gorzej, natomiast co piąty uważał, że jest mało prawdopodobne, aby coś się zmieniło na lepsze (wykres 3). Podobne wartości notowano u progu 2009 r., kiedy do Rosji docierał międzynarodowy kryzys finansowy, a jeszcze mniej optymistyczne pod koniec lat 90. w trakcie największych trudności gospodarczych współczesnej Federacji. Jednocześnie, odnotowano spadek liczby osób, które mają nadzieję, iż w kolejnym roku będzie lepiej lub nawet są tego pewne. Jednak, nadal $40 \%$ Rosjan z ogromną nadzieją na lepsze patrzy w przyszłość.

Umiarkowanego optymizmu można się doszukiwać w wynikach badań, w których pytano Rosjan o prognozy dotyczące kryzysu. U progu 2016 r. znacznie, bo o połowę, zmalała liczba osób, które były przekonane, iż w najbliższym roku dojdzie do poważnego kryzysu gospodarczego (tabela 1). Wzrosła natomiast, choć już nie tak spektakularnie,

${ }^{1}$ Określenia „godne ubóstwo” na aktualną sytuację znacznej części Rosjan używa Marina Krasilnikov, kierownicza badań nad dochodami i konsumpcją Centrum Analitycznego Lewady w artykule Тяжельй год: как россияне справляются с кризисом (Тяжельй). 
Wykres 3. Oczekiwania Rosjan wobec kolejnego roku (badania przeprowadzane corocznie w grudniu od 1990 do 2015 r.)

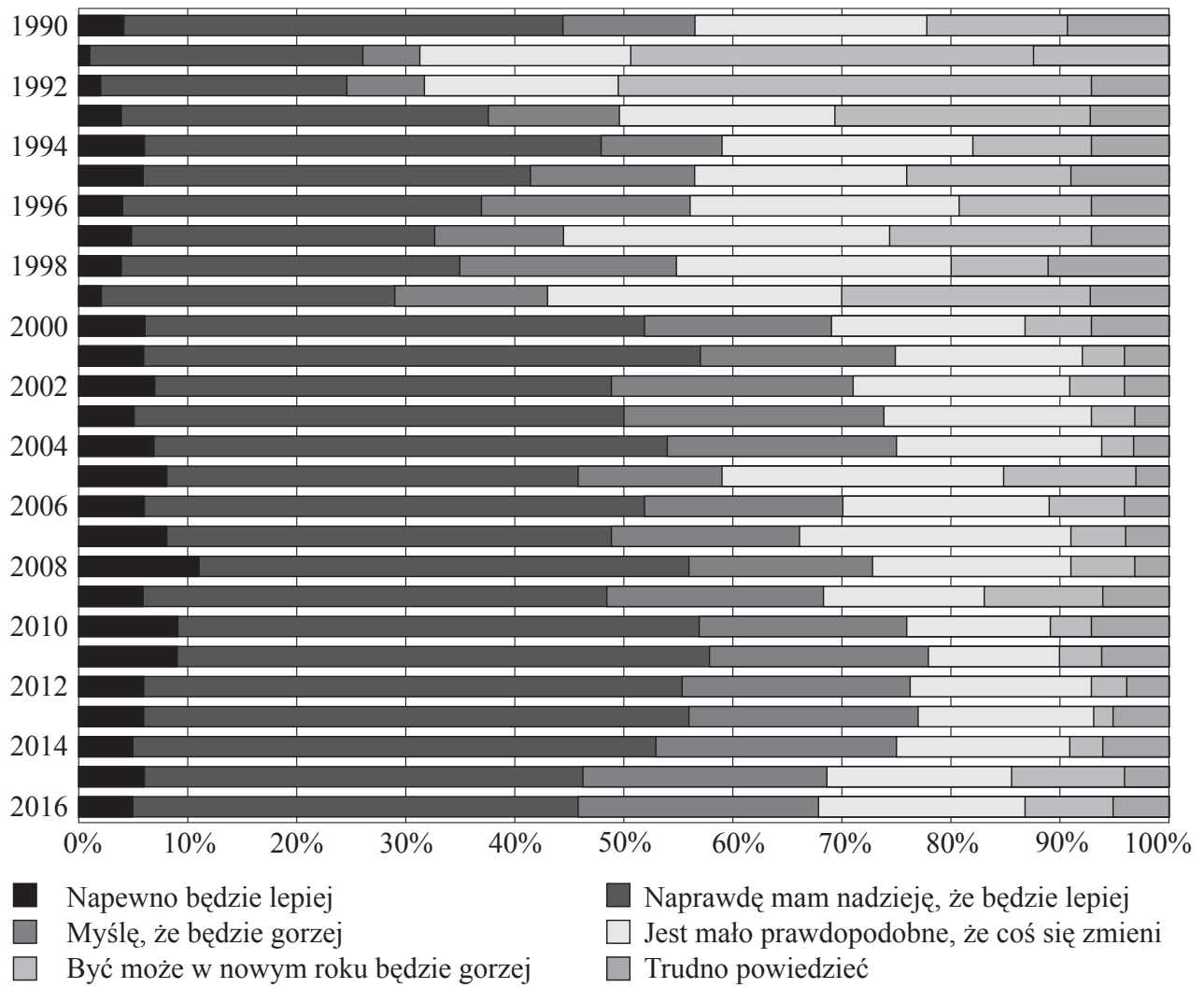

Źródło: Opracowanie własne na podstawie danych Centrum Analitycznego Lewady (Ожидания).

liczba osób, które takiego kryzysu w 2016 r. nie przewidują (z mniejszym lub większym przekonaniem co trzeci Rosjanin). Co piąty obywatel Federacji nie potrafi natomiast sformułować swojego zdania na ten temat, co może oznaczać pewną dezorientację oraz niechęć do zastanawiania się nad niepewną przyszłością.

Tabela 1

Opinia Rosjan na temat możliwości pojawienia się kryzysu gospodarczego podobnego do tego, który mial miejsce w 2008 r. (w \%)

\begin{tabular}{|c|c|c|c|c|c|c||}
\hline \hline $\begin{array}{l}\text { Czy to możliwe, aby } \\
\text { (taki jaki byt w 2008 roku)? }\end{array}$ & $\begin{array}{c}\text { przysztym roku } \\
\text { (20k }\end{array}$ & $\begin{array}{c}\text { Zdecydowanie } \\
\text { tak }\end{array}$ & Raczej tak & Raczej nie & $\begin{array}{c}\text { Zdecydowanie } \\
\text { nie }\end{array}$ & $\begin{array}{c}\text { Trudno } \\
\text { powiedzieć }\end{array}$ \\
\hline 1 & 2 & 3 & 4 & 5 & 6 \\
\hline 2016 & 11 & 36 & 27 & 6 & 20 \\
\hline 2015 & 20 & 42 & 20 & 5 & 13 \\
\hline 2014 & 6 & 32 & 40 & 5 & 17 \\
\hline
\end{tabular}




\begin{tabular}{|c|c|c|c|c|c||}
\hline 1 & 2 & 3 & 4 & 5 & 6 \\
\hline 2013 & 6 & 33 & 37 & 8 & 16 \\
\hline 2012 & 2 & 37 & 34 & 7 & 19 \\
\hline 2011 & 7 & 28 & 40 & 7 & 19 \\
\hline 2007 & 3 & 18 & 44 & 12 & 22 \\
\hline 2006 & 5 & 24 & 45 & 13 & 12 \\
\hline
\end{tabular}

Źródło: Opracowanie własne na podstawie danych Centrum Analitycznego Lewady (Ожидания).

\section{Prognozy protestów i gotowość społeczeństwa do udziału w nich}

Trudna sytuacja gospodarcza oraz brak powszechnej nadziei na to, iż w najbliższym czasie problemy ekonomiczne znajdą rozwiązane nie znajduje odzwierciedlenia w opiniach Rosjan na temat ewentualnych prognozowanych masowych wieców i protestów. Ponad połowa Rosjan twierdzi, iż w 2016 r. nie odbędą się żadne masowe manifestacje, a tylko co trzeci obywatel Federacji widzi taką możliwość (ale nie jest o tym zupełnie przekonany, tabela 2). Na postawie wyników badań rosyjskiej opinii publicznej, można zauważyć, że w ciągu ostatnich dziesięciu lat, masowe protesty były według Rosjan najbardziej prawdopodobne były w roku $2012^{2}$. W kolejnych latach, wraz z wprowadzanymi systematycznie przez władzę ograniczeniami funkcjonowania opozycji w Rosji, oczekiwania Rosjan wobec potencjalnych masowych protestów stopniowo malały.

Tabela 2

Opinia Rosjan na temat możliwości pojawienia się masowych wieców i protestów (w \%)

\begin{tabular}{|c|c|c|c|c|c||}
\hline \multicolumn{6}{|c|}{ Czy to możliwe, aby w przyszlym roku w Rosji miaty miejsce masowe wiece i protesty? } \\
\hline Rok & $\begin{array}{c}\text { Zdecydowanie } \\
\text { tak }\end{array}$ & Raczej tak & Raczej nie & $\begin{array}{c}\text { Zdecydowanie } \\
\text { nie }\end{array}$ & $\begin{array}{c}\text { Trudno } \\
\text { powiedzieć }\end{array}$ \\
\hline 2016 & 4 & 27 & 37 & 18 & 15 \\
\hline 2015 & 4 & 28 & 38 & 16 & 14 \\
\hline 2014 & 6 & 37 & 35 & 8 & 15 \\
\hline 2013 & 5 & 45 & 31 & 8 & 12 \\
\hline 2012 & 6 & 50 & 25 & 5 & 13 \\
\hline 2011 & 6 & 40 & 28 & 8 & 18 \\
\hline 2007 & 5 & 27 & 36 & 13 & 19 \\
\hline
\end{tabular}

Źródło: Opracowanie własne na podstawie danych Centrum Analitycznego Lewady (Ожидания).

Powszechny brak wiary w to, że w najbliższym czasie mogą mieć miejsce w Rosji masowe protesty potwierdzają również badania, w których Rosjanie zostali poproszeni o opinię na temat możliwości pojawienia się protestów motywowanych ekonomicznie (przeciwko obniżającemu się poziomowi życia) - tylko co piąty Rosjanin pod koniec

${ }^{2}$ Sfałszowane wyniki wyborów do Dumy Państwowej w grudniu 2011 r. zmobilizowały tysiące Rosjan do zamanifestowania na rosyjskich ulicach i placach (głównie w największych miastach Federacji) swojego niezadowolenia. Obserwatorzy tamtych wydarzeń nazwali je Białą Rewolucją w ramach której w protestach wzięło udział nawet około 100 tysięcy obywateli Rosji. 
2015 r. był przekonany, że takie manifestacje mogą mieć miejsce (wykres 5). Jeszcze mniej osób deklarowało udział w takich potencjalnych protestach - tylko co dziesiąty obywatel Federacji. Największy potencjał protestu z przyczyn ekonomicznych można było obserwować w Rosji w drugiej połowie lat 90. (a szczególnie w latach 1997-1999, kiedy Federacja Rosyjska borykała się z gigantycznym kryzysem gospodarczym), kiedy to masowych protestów oczekiwała blisko połowa Rosjan. Potencjał protestu był również dosyć wysoki w drugiej połowie pierwszej dekady lat dwutysięcznych, a szczególnie w roku 2009, kiedy do Federacji Rosyjskiej dotarł światowy kryzys finansowy.

Wykres 4. Potencjal protestu motywowanego ekonomicznie na przestrzeni lat 1994-2015 (Centrum Analityczne Lewady)

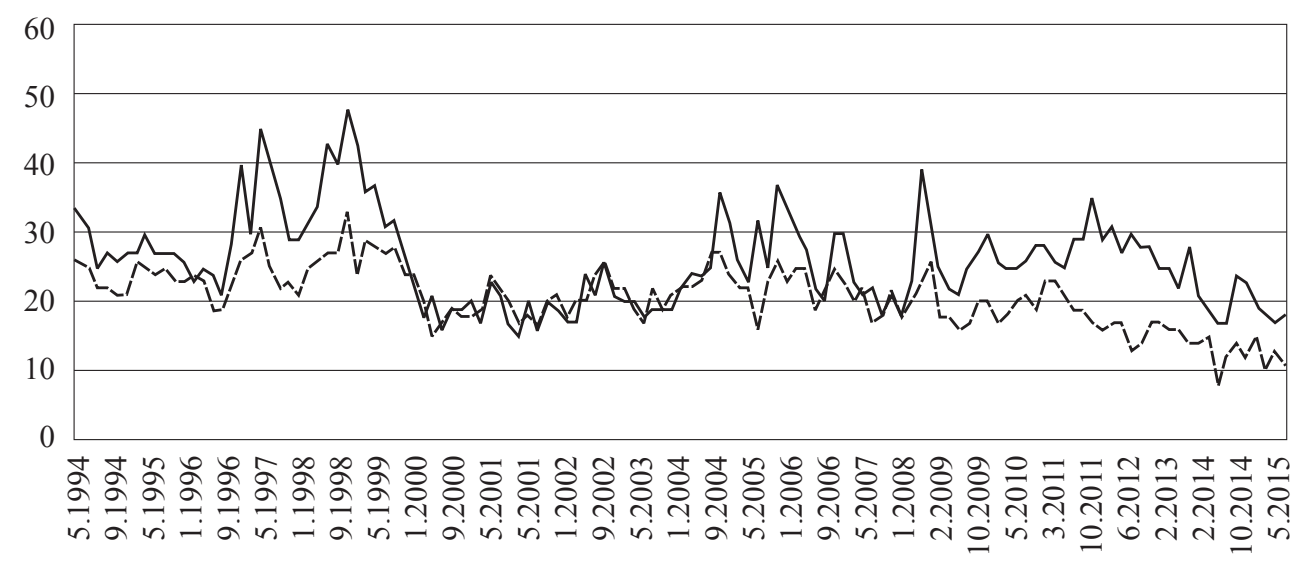

—-Protest możliwy ---- Będę uczestniczyć

Źródło: Opracowanie własne na podstawie danych Centrum Analitycznego Lewady (Оценка).

Podobne badania wśród rosyjskich obywateli prowadzi również regularnie Rosyjskie Centrum Badania Opinii Publicznej (Всероссийский центр изучения общественного мнения - ВЦИОМ) - choć w tych wynikach potencjał protestów motywowanych ekonomicznie jest nieznacznie wyższy (dwadzieścia kilka do maksymalnie 30\% Rosjan uznaje takie protesty za możliwe), to wyraźnie widać, że od dziesięciu lat nie obserwowano większych zmian (z wyjątkiem lat 2014-2015, kiedy potencjał uległ obniżeniu, prawdopodobnie na skutek przedstawianej powszechnie jako sukces Federacji Rosyjskiej aneksji Krymu, wykres 5).

Kryzys gospodarczy, z którym od ponad roku zmaga się rosyjska gospodarka, a przede wszystkim rosyjscy obywatele, pozostaje na razie bez wpływu na oczekiwania Rosjan wobec potencjalnych protestów motywowanych ekonomicznie. Zdecydowana większość obywateli Federacji uznaje ewentualne masowe manifestacje przeciwko pogarszającym się warunkom życia za mało prawdopodobne, niewielka też grupa Rosjan deklaruje udział w takich potencjalnych wystąpieniach. Stąd można uznać, iż na obecnym etapie kryzysu, trudno oczekiwać powszechnych protestów rosyjskich obywateli przeciwko trudnej sytuacji gospodarczej. 
Wykres 5. Potencjał protestu motywowanego ekonomicznie na przestrzeni lat 2001-2016 (ВЦИОМ)

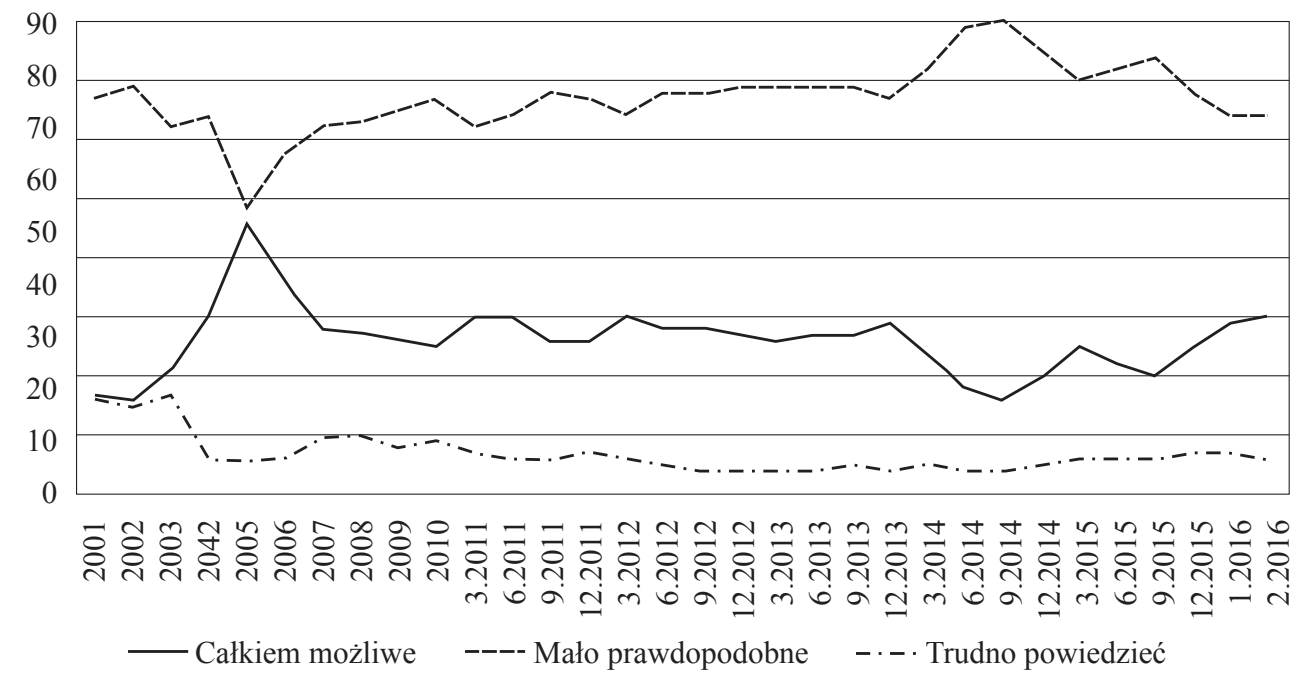

Źródło: Opracowanie własne na podstawie danych Rosyjskiego Centrum Badania Opinii Publicznej (Протестный).

\section{Przyczyny niechęci Rosjan wobec nawet potencjalnego udziału w protestach przeciwko władzy}

Trudno dziś jednoznacznie wskazać, dlaczego zdecydowana większość Rosjan, pomimo pogarszającej się sytuacji gospodarczej i coraz dotkliwiej odczuwanych przez statystycznych Rosjan skutków kryzysu, nie zamierza organizować, ani brać udziału w masowych protestach przeciwko władzy. Łatwiej natomiast zbudować wieloaspektowy katalog potencjalnych przyczyn, które mogłyby to zjawisko tłumaczyć:

- większość protestów, które miały miejsce w ostatnich latach (ale już po manifestacjach z przełomu 2011/2012) była organizowana w obronie interesów konkretnych grup, najczęściej zawodowych - lekarzy, nauczycieli, kierowców ciężarówek. Jednak takie działania nie przyciagają poparcia znacznej części Rosjan, ponieważ przeważa opinia „nas to nie dotyczy”, „to nie w naszym interesie”. A bez solidarności z innymi grupami wszystkie protesty są skazane na pozostanie jednorazowymi akcjami, nie mają szansy na stworzenie szerokiego ruchu protestu, a tym bardziej nie mają szans, aby wstrząsnąć podstawami ładu politycznego (Волков, 2015);

- poparcie dla protestów czy gotowość udziału w nich wzrasta w Rosji dopiero w momencie, kiedy się one zaczną - dopiero doniesienia o protestujących, wychodzących na ulice współobywatelach, mobilizują pozostałych do działania (Волков, 2015),

- trudno dziś połączyć interesy bogatych, wykształconych, z dostępem do Internetu, którzy stanowili trzon protestów w 2012 r. z interesami kierowców ciężarówek, którzy dziś są bodaj jedyną grupą organizującą protesty;

- klasa średnia, która dominowała w grupie protestujących po wyborach do Dumy Państwowej w 2011 r., dziś - w czasie kryzysu - skupia się na przetrwaniu oraz 
zabezpieczeniu swojego majątku, dlatego też trudno oczekiwać masowego jej zaangażowania w potencjalne protesty. Dodatkowo, w opinii Pawła Kazarina ,jej upadek nie będzie miał wpływu na rosyjską politykę, ponieważ elity rządzące nie biorą tej klasy pod uwagę przy podejmowaniu decyzji” (Debata);

- sytuacja najbiedniejszych, którzy mogliby stanowić tym razem trzon protestu, nie jest aż tak zła, żeby zaryzykowali oni udział w protestach, w których mogą stracić wszystko. Według Denisa Volkova „Rosjanie mają też ciagle nadzieję na wprowadzenie - w obliczu wysokiej inflacji - indeksacji płac i emerytur. Dopiero jeśli tak się nie stanie, może dojść do protestów" (Debata). Dowodzi to, iż uzależnienie od potencjalnych transferów ze strony państwa skutecznie powstrzymuje przed udziałem w protestach;

- piętnaście lat sprawowania władzy przez Władimira Putina to okres znacznego systematycznego podnoszenia się średniego poziomu życia Rosjan (szczególnie w stosunku do drugiej połowy lat 90., kiedy Rosja zmagała się z gigantycznym kryzysem) - trudności, których dziś doświadczają Rosjanie, trudno porównywać z tymi sprzed blisko dwóch dekad, dlatego też większość rosyjskich obywateli nie chce zaryzykować wszystkiego, co posiada (a posiada znacznie więcej niż w latach 90.) i brać udziału w protestach (Łobuszewska, Kazimierska, Mańkowski, 2015, s. 20);

- kryzys rosyjskiej gospodarki, który mógłby stać się dziś głównym impulsem do masowych protestów, nie istnieje w rosyjskiej przestrzeni medialnej - „Jak mówiła Jekaterina Romanowa, społeczeństwu wmawia się, że kryzys jest spowodowany wyłącznie sankcjami zachodnimi, nie zaś nieefektywnym modelem gospodarczym i problemami wewnętrznymi - tych bowiem Rosja jakoby nie posiada" (Debata). Zdecydowana większość Rosjan ufa W. Putinowi, który nieustannie zapewnia, że rosyjska gospodarka maksymalnie w ciagu dwóch lat odbije się od dna i wszystkie problemy gospodarcze się skończą ${ }^{3}$. Dodatkowo, przeniesienie odpowiedzialności na „wrogi Rosji Zachód” wyklucza możliwość oskarżania władz rosyjskich, a co za tym idzie, protestowania przeciwko nim.

\section{Podsumowanie}

Aktualny kryzys gospodarczy, którego doświadczają Rosjanie, przywołuje pytanie o trwałość umowy społecznej, która przez ostatnie piętnaście lat obowiązywała w Federacji. Według opinii Pawła Kazarina (współpracownika Centrum Carnegie) „obecna rzeczywistość ekonomiczna jest wynikiem rzeczywistości politycznej i doprowadzi do konsekwencji politycznych. Jedną z tych konsekwencji może być upadek swego rodzaju umowy społecznej, w ramach której obywatele zrzekali się wolności politycznej w zamian za zapewnienie dobrobytu przez władzę. Kryzys może też doprowadzić do narastania konfliktu wśród rosyjskich elit” (Debata). Również w opinii Zespołu Rosyjskiego

${ }^{3} \mathrm{Z}$ badań opinii publicznej przeprowadzanych przez Centrum Analityczne Lewady wynika, iż około połowa Rosjan wierzy w zapewnienia W. Putina (poczynione podczas obchodów 70. rocznicy zwycięstwa nad hitlerowskimi Niemcami podczas II wojny światowej), iż recesja potrwa jeszcze tylko maksymalnie dwa lata. Co więcej, Rosjanie, zapytani podczas badań fokusowych, o wyjaśnienie źródeł tych silnych przekonań, odpowiada po prostu „Tak powiedział Putin” (Volkov, 2016). 
OSW formuła tej swoistej umowy społecznej uległa wyczerpaniu, ponieważ „pogorszenie sytuacji ekonomicznej uniemożliwia władzom zapewnianie obywatelom stałej poprawy poziomu życia, co dotąd gwarantowało wysokie poparcie dla rządzących" (Menkiszak, 2015, s. 6). W tej sytuacji pojawia się również pytanie, czy dotychczasowa umowa społeczna nie została przedefiniowana - czy nie nastąpiła wymiana gwarantowanego dotychczas przez państwo dobrobytu na oferowane dziś poczucie wielkości, mocarstwowości, swoisty imperializm, który wymaga poświęceń ze strony społeczeństwa, choćby w postaci konieczności borykania się z kryzysem gospodarczym.

Jednak, abstrahując od debaty na temat kondycji umowy społecznej pomiędzy władzą a Rosjanami i jednocześnie biorąc pod uwagę bierność społeczeństwa oraz ogromne trudności w zmobilizowaniu większej grupy osób nie w imię partykularnych interesów, a abstrakcyjnego dobra wspólnego, trudno dziś przewidywać, aby w najbliższym czasie miało dojść do masowych protestów przeciwko władzy. Najbiedniejsi Rosjanie wciąż radzą sobie z rosnącymi cenami i malejącymi dochodami, ograniczając swoje potrzeby do minimum; klasa średnia, która ewentualnie mogłaby być zalążkiem i organizatorem protestów, skupiona jest na radzeniu sobie z kryzysem i próbach ocalenia reszty majątku; natomiast elity od władzy uzależnione, obawiają się jej zmiany, z uwagi na niemożliwy do przewidzenia scenariusz przemian.

\section{Bibliografia}

Bloomberg включил Россию в топ-5 худиих экономик 2016 года, 11.01.2016, forbes.ru, http://www. forbes.ru/news/310005-bloomberg-vklyuchil-rossiyu-v-top-5-khudshikh-ekonomik-2016goda, 13.01.2016.

Co czeka rosyjskq gospodarke w 2016 roku?, 24.12.2015, pl.sputniknews.com, http://pl.sputniknews. com/gospodarka/20151224/1716798/2016-rating-gospodarka.html, 12.01.2016.

Debata: Gospodarka Rosji w czasach kryzysu. Omówienie spotkania, 20.10.2015, pl-ru.club, http:// pl-ru.club/gospodarka-rosji-w-czasach-kryzysu/, 3.02.2016.

Domańska M., Kryzysowy budżet Rosji AD 2016, 9.12.2015, osw.waw.pl, http://www.osw.waw.pl/pl/ publikacje/analizy/2015-12-09/kryzysowy-budzet-rosji-ad-2016, 13.01.2016.

Fischer E., Korekta rosyjskiego budżetu na 2015 rok: próba utrzymania status quo, 18.03.2015, osw. waw.pl, http://www.osw.waw.pl/pl/publikacje/analizy/2015-03-18/korekta-rosyjskiego-budzetu-na-2015-rok-proba-utrzymania-status-quo, 13.01.2016.

Inoziemcow W., Gospodarka: kolejna fala kryzysu, 19.11.2015, media-w-rosji.blogspot.com, http:// media-w-rosji.blogspot.com/2015/11/gospodarka-kolejna-fala-kryzysu.html, 12.12.2015.

Kośka M., Rosja sobie nie radzi, ale tego nie przyzna, 21.12.2015, obserwatorfinansowy.pl, http://www. obserwatorfinansowy.pl/forma/rotator/rosja-sobie-nie-radzi-ale-tego-nie-przyzna/, 12.01.2016.

Łobuszewska A. (red.), Kazimierska K., Mańkowski W. (2015), Kryzys gospodarczo-finansowy w Rosji. Uwarunkowania, przejawy, perspektywy, Ośrodek Studiów Wschodnich, Warszawa.

Menkiszak M. (red.) (2015), Późny Putin. Koniec rozwoju, koniec stabilności, Ośrodek Studiów Wschodnich, Warszawa.

Menkiszak M., Fischer E., Kryzys putinowskiego modelu gospodarki w Rosji, 17.12.2014, osw.waw. pl, http://www.osw.waw.pl/pl/publikacje/analizy/2014-12-17/kryzys-putinowskiego-modelugospodarki-w-rosji, 12.01.2016.

Miedwiediew: Dowiedliśmy samowystarczalności naszej gospodarki, 9.12.2015, pl.sputniknews.com, http://pl.sputniknews.com/gospodarka/20151209/1610791/Miedwiediew-samowystarczalnosc-rosyjskiej-gospodarki.html, 19.12.2015. 
Putin: pomimo spadku ceny ropy naftowej rosyjska gospodarka pokonała kryzys, 17.12.2015, pl.sputniknews.com, http://pl.sputniknews.com/swiat/20151217/1663507/Putin-liczby-gospodarka. html, 19.12.2015.

Ropa - notowania surowców, bankier.pl, http://www.bankier.pl/inwestowanie/profile/quote.html?symbol=ROPA, 24.02.2016.

Rosja - Inflacja, pl.tradingeconomics.com, http://pl.tradingeconomics.com/russia/inflation-cpi, 24.02.2016.

Rosja - roczne tempo wzrostu PKB, pl.tradingeconomics.com, http://pl.tradingeconomics.com/russia/ gdp-growth-annual, 24.02.2016.

Volkov D., Are Russians Feeling the Economic Crisis?, 1.03.2016, carnegie.ru, http://carnegie.ru/commentary/2016/03/01/are-russians-feeling-economic-crisis/iuol, 3.03.2016.

Волков Д., За дальнобоев: ждать ли в России массовых протестов, 1.12.2015, Carnegie Center, http://carnegie.ru/commentary/2015/12/01/ru-62128/imh9, 3.02.2016.

Красильникова М., Тяжельй год: как россияне справляются с кризисом, 25.12.2015, rbc.ru, http:// www.rbc.ru/opinions/society/25/12/2015/567d15d49a794739d8c8a826, 17.01.2016.

Ожидания от будущего года, 28.12.2015, Centrum Analityczne Lewady, http://www.levada. $\mathrm{ru} / 2015 / 12 / 28 /$ ozhidaniya-ot-budushhego-goda/, 24.02.2016.

Оиенка текущего положения дел в стране, Centrum Analityczne Lewady, http://www.levada.ru/ indikatory/polozhenie-del-v-strane/, 1.02.2016.

Протестный потенциал, Rosyjskie Centrum Badania Opinii Publicznej (ВЦИОМ), http://wciom.ru/ news/ratings/protestnyj_potencial/, 25.02.2016.

Трудный год: как россияне спрабляются с кризисом, 28.12.2015, Centrum Analityczne Lewady, http://www.levada.ru/2015/12/28/tyazhelyj-god-kak-rossiyane-spravlyayutsya-s-krizisom/, 2.02.2016.

\title{
The potential for economically motivated protests - the case of today's Russian Federation
}

\begin{abstract}
Summary
The activities of the Russian political opposition have been significantly limited after the mass protests at the turn of 2011 and 2012. Numerous changes in the law resulted in a significant decrease in the number of entities that could continue opposition activity in the sphere of politics. At the same time, the deepening economic crisis and the deteriorating economic situation of the broad masses of Russians revealed a hitherto undeveloped space where the dissatisfaction of Russian citizens with the actions of the authorities began to be manifested in recent months. This paper aims to analyze the current socio-economic situation of the Russian Federation and indicate the possible manifestations of the economically motivated protests by Russians. The analysis will be based on macroeconomic indicators, the results of research into Russian public opinion and an analysis of information on the potential protests published in the Russian media (mostly social media). As a result, the paper may form a contribution to the discussion on the potential relationship between the lack of stability in such matters as the sense of economic and social security and the propensity to participate in protests against the government.
\end{abstract}

Key words: opposition in the Russian Federation; protests against the government; Russia's economy; public perception of the crisis 
